\title{
Application Of Anaerobic Ammonia Oxidation (Anammox) Process In Municipal Mainstream Wastewater Treatment
}

\author{
Yinghua $\mathrm{Li}^{1, \mathrm{a}, \mathrm{b}}$ \\ aGuangxi Key Laboratory of Environmental Pollution Control Theory and Technology, Guilin \\ University of Technology, Guilin 541004, P.R. China; \\ ${ }^{b}$ Guangxi Collaborative Innovation Center for Water Pollution Control and Water Safety in Karst \\ Area, Guilin University of Technology, Guilin 541004, P.R. China; \\ a2010053@glut.edu.cn,b103375916@qq.com
}

\begin{abstract}
Keywords: anaerobic ammonium oxidation; anammox; mainstream; municipal wastewater; influencing factors; practical application.

Abstract. Anaerobic ammonia oxidation (Anammox) process is a new nitrogen removal technology, which has prominent advantages such as zero need of organic carbon sources. While lack of organic carbon sources is very common in nitrogen removal by using traditional nitrification-denitrification technology treating municipal wastewater. If the anammox process is applied to treat the municipal mainstream wastewater directly, a revolutionary change might happen in municipal sewage treatment plant. This paper introduces most recent researches of anammox process application in treating municipal mainstream wastewater and the application problems are indicated. The suggestions are proposed for future studies of anammox application in municipal mainstream wastewater treatment.
\end{abstract}

\section{Introduction}

Anaerobic ammonium oxidation (Anammox) process has been recognized as one of the most economical biological nitrogen removal technologies due to its advantages of no need of organic carbon source, high denitrification load, low operation cost and small space occupation [1,2]. The successful application of anammox technology to municipal mainstream wastewater treatment plant will make a revolutionary change in municipal sewage treatment plant [3]. As Siegrist et al. [4] pointed out anammox technology has resulted in increasing methane production, reducing aeration and achieving energy self-sufficiency in municipal wastewater treatment plant. At present, anammox technology applied in municipal wastewater treatment, mainly faces organic matter, dissolved oxygen, temperature, nitrite and other suppression problems, such as sludge retention and the source of nitrite.

\section{The main application obstacle of anammox in municipal mainstream wastewater treatment}

The effect of organic matter. The original purpose of municipal wastewater treatment is to remove COD from water. After that, in order to avoid the eutrophication of receiving water body, further nitrogen and phosphorus removals are needed. As for the traditional nitrification and denitrification process, nitrification is the first step, and then denitrification using COD as electron receptor is followed. However, most CODs are removed at the first step, resulting in the lack of carbon sources for denitrification. Thus, additional carbon sources are usually added during the denitrification stage. Anammox process doesn't need organic carbon sources, which can be replaced by nitrite. However, researches have shown that the presence of COD in wastewater may affect anammox activities, and the organic matter might have a direct negative effect on the anammox process. For example, Chamchoi et al. [5] used anammox reactor to test and found that the anammox activity gradually decreased when the COD increased gradually between 100-400 mg/L. Tan et al. [6] used sugar as carbon source to study the effect of organic compounds on CANON process, and found that when the COD less than $100 \mathrm{mg} / \mathrm{L}$, the aeration flow of adjustment tank $0.6 \mathrm{~L} / \mathrm{min}$, there is no effect on the performance of the anammox process. However, when the concentration was increased to more than 
$100 \mathrm{mg} / \mathrm{L}$, the performance of the reactor tended to be unstable. Therefore, the influent COD should be monitored, and it is recommended that a concentration of less than $150 \mathrm{mg} / \mathrm{L}$ to be controlled.

The effect of dissolved oxygen (DO). The DO used in traditional municipal wastewater treatment is generally beyond $2 \mathrm{mg} / \mathrm{L}$. Strous et al. [7] reported that high DO concentration will inhibit the activity of anammox bacteria. When DO concentration of air saturation is $0.5-2.0 \%$, the activity of anammox bacteria will be completely inhibited. The activity of anammox bacteria might be still inhibited at low oxygen (less than $0.5 \%$ ). Researches show that DO has a negative effect on anammox bacteria, however it is reversible and the activity can be restored when the oxygen is removed. In practice, there will be some aerobic bacteria such as ammonia oxidizing bacteria (AOB) in the anammox reactor, which can reduce the effect of DO on anammox bacteria. The AOB can provide electron acceptor for ammonia bacteria. Therefore, the inhibition of DO to anammox bacteria in municipal sewage can be overcome through DO control combined with the role of AOB.

The effect of temperature. The temperature can affect the activity of the enzyme in the anammox reaction, which affects the biological characteristics of the anammox bacteria. Anammox bacteria are mesophilic organisms, and the most suitable temperature ranges of $30-40^{\circ} \mathrm{C}[8]$. The temperature of municipal wastewater is generally $8-30^{\circ} \mathrm{C}$, which is sometimes lower than the appropriate temperature of anammox process. Cema et al. [9] operated the anammox rotating biological disk at a temperature of $17^{\circ} \mathrm{C}$ with a TN load of $0.5 \mathrm{~kg} /\left(\mathrm{m}^{3} \bullet \mathrm{d}\right)$. In the experiments, it was found that anammox bacteria are still active despite low loads at lower temperatures. Therefore, temperature does not have a significant impact on anammox bacteria at municipal wastewater temperatures, the operational effectiveness can be assured by reducing the nitrogen load on the influent at lower temperatures.

The inhibition of nitrite. A certain concentration of $\mathrm{NO}_{2}{ }^{-} \mathrm{N}$ has inhibitory effect on anammox bacteria, and different researchers can reach agreement. However, it has different conclusions about the range of inhibition and the definitions of inhibition. Some scholars refer to the concentration that the activity begins to decline as the inhibitory concentration, and some scholars define the concentration that the anammox bacterium were completely inhibited. The concentration of $\mathrm{TN}$ in municipal wastewater does not exceed $100 \mathrm{mg} / \mathrm{L}$. If using anammox process, it needs to be transformed into a $\mathrm{NO}_{2}{ }^{-} \mathrm{N}$ concentration of lower than $60 \mathrm{mg} / \mathrm{L}$, which is lower than $\mathrm{NO}_{2}{ }^{-} \mathrm{N}$ concentration for the inhibitory concentration of anammox bacteria. Therefore, the concentration of the converted $\mathrm{NO}_{2}{ }^{-} \mathrm{N}$ in municipal sewage will not affect the anammox bacteria.

\section{The types of anammox process}

One stage. Completely autotrophic nitrogen-removal over nitrite (CANON) process is a single-stage denitrification process, through the control of DO in the short-term nitrification and anammox separation operation, so as to achieve the purpose of denitrification [10]. The principle of the process is that in a single reactor or biofilm, where $\mathrm{AOB}$ oxidizes part of $\mathrm{NH}_{4}{ }^{+}$to $\mathrm{NO}_{2}{ }^{-}$in micro-oxygen conditions, and anammox bacteria convert the remaining $\mathrm{NH}_{4}{ }^{+}$and the generated $\mathrm{NO}_{2}{ }^{-}$in anaerobic conditions to $\mathrm{N}_{2}$. As the AOB and anammox belong to autotrophic bacteria, so exogenous organic matter was not needed in the process of CANON. Compared with the traditional denitrification process, CANON process can reduce about $63 \%$ of the oxygen supply and $100 \%$ of the carbon source.

The use of CANON to treat municipal wastewater can be carried out from two aspects, using the biofilm process, or using the form of granular sludge. For the latter, Winkler et al. [11] combined aerobic granular sludge with anammox to treat normal-temperature wastewater, and the temperature was limited to $(18 \pm 3){ }^{\circ} \mathrm{C}$. Simultaneous short-range nitrification and anammox could be obtained when the $\mathrm{C} / \mathrm{N}$ ratio was 0.5 and $\mathrm{DO}$ was $1.5 \mathrm{mg} / \mathrm{L}$.

Two stages. Nitrification/anammox process is the most commonly used anammox process in sewage treatment nowadays. In the sewage treatment, it is mainly divided into two stages where reactions are carried out in different reactors [12]. The basic principle is to separate the process of partial nitrification and anammox. First is the nitrification stage, where half of the ammonia nitrogen will be transformed into nitrite nitrogen by autotrophic nitrification. This stage can be controlled by 
temperature, SRT, $\mathrm{pH}, \mathrm{DO}$ and other conditions. The effluent $\mathrm{NH}_{4}{ }^{+}-\mathrm{N}$ and $\mathrm{NO}_{2}{ }^{-}-\mathrm{N}$ ratio is about $1: 1$, which will be as the influent of anammox reactor. The second is the anammox stage. The ammonia nitrogen and the transformed nitrite nitrogen in the wastewater will be converted to nitrogen by anammox bacteria to achieve the purpose of denitrification. The reactions are shown as follows [13]:

$$
\mathrm{NH}_{4}{ }^{+}+0.75 \mathrm{O}_{2} \rightarrow 0.5 \mathrm{NH}_{4}{ }^{+}+0.5 \mathrm{NO}_{2}{ }^{-}+0.5 \mathrm{H}_{2} \mathrm{O}+\mathrm{H}^{+}
$$

$0.5 \mathrm{NH}_{4}{ }^{+}+0.5 \mathrm{NO}_{2}{ }^{-} \rightarrow 0.5 \mathrm{~N}_{2}+\mathrm{H}_{2} \mathrm{O}$

Compared with the traditional biological nitrification-denitrification, the two stage anammox process has the following advantages:

(1) Nitrification is controlled in the nitrosation stage, which can save about $25 \%$ of the gas supply and save power consumption;

(2) Reduce hydraulic retention time and reduce reactor volume and footprint;

(3) The denitrification process of the traditional denitrification process needs additional carbon source, but this process does not need external carbon source.

(4) Good sedimentation performance and high biological phase concentration to avoid sludge expansion.

(5) Sludge yield is low, saving sludge disposal costs.

\section{Applications of anammox process in municipal wastewater treatment}

Low ammonia nitrogen wastewater. In recent years, many researchers applied the anammox process into low ammonia nitrogen wastewater treatment. Scholars et al. [14] have found that anammox bacteria can enter the underground anaerobic area from the surface of the sea and consume inorganic nitrogen in the Black Sea. Through the observation and study of this natural phenomenon, he boldly made the conjecture that the use of anammox process might be able to react under low ammonia nitrogen environment. Fu et al. [15] also conducted for a period of $165 \mathrm{~d}$ of the experiment, after treated by anammox, $\mathrm{NH}_{4}{ }^{+}-\mathrm{N}$ removal rate reached $93 \%$, while the $\mathrm{NO}_{2}{ }^{-}-\mathrm{N}$ removal rate was as high as $100 \%$. Huang et al. [16] treated ASBBR effluent with low concentration of ammonia nitrogen at a temperature of $(30 \pm 1){ }^{\circ} \mathrm{C}$, nitrogen load of $0.025 \mathrm{~kg} /\left(\mathrm{m}^{3} \cdot \mathrm{d}\right)$ and the combination of fillers as biological carriers. After 51 days, the anammox reactor was started. The effluent $\mathrm{NH}_{4}{ }^{+}-\mathrm{N}$ and TN were $2.9 \mathrm{mg} / \mathrm{L}$ and $5.06 \mathrm{mg} / \mathrm{L}$, respectively, and the average TN removal rate was $84.2 \%$. Hu et al. [17] adopted the integrated partial nitrification anammox process. The original SBR $(5 \mathrm{~L})$ was operated at $25{ }^{\circ} \mathrm{C}$, the start-up period was 12 days. The reactor was operated steadily for more than 300 days under this temperature condition. No nitrite accumulated and NRE exceeded $90 \%$. At the same time, the study also proves that the sludge of high load reactor can be used as inoculation sludge for the anammox reactor of low temperature and low ammonia nitrogen municipal sewage. The experimental results above verify the feasibility of the anammox process in the application of low ammonia nitrogen waste water.

High ammonia wastewater. At present, the applications of anammox process are mainly in the treatment of high ammonia nitrogen wastewater. Applications of anammox process for high ammonia nitrogen wastewater treatment, are mainly in the following two aspects. The first is sludge digestion treatment. van Dongen et al. [18] first studied the feasibility of partial nitrification/ anammox process for treating digested sludge supernatant from Dutch Dokhaven Sewage Treatment Plant. A significant denitrification rate of over $80 \%$ was obtained. Fux et al. [19] also used two stage anammox process treating digestor in pilot scale in Switzerland. By using a SBR of $1600 \mathrm{~L}$, influent ammonia nitrogen of $620-650 \mathrm{mg} / \mathrm{L}$, the $\mathrm{pH}$ of $7.3-7.5$, the temperature of $26-28{ }^{\circ} \mathrm{C}$, the nitrogen load rate (NLR) was up to $0.65 \mathrm{kgN} /\left(\mathrm{m}^{3} \bullet \mathrm{d}\right)$, and the nitrogen removal efficiency (NRE) reached $92 \%$. The sludge production was almost zero during the study. Based on the above results, the researchers enlarged the reactor directly and built the first full-scale anammox process in the world, which has been officially operated at Dokhaven Sewage Treatment Plant in 2002. The volume of the anammox reactor is $70 \mathrm{~m}^{3}$ and the treating capacity is $750 \mathrm{kgN} / \mathrm{d}$ [20]. 
The city produces a lot of rubbish every day, and if these rubbish landfills for a long time, a kind of high ammoniacal permeate will generate. The imbalance between carbon and nitrogen is caused by long time digestion, which also leads to a high ammonia nitrogen wastewater difficult to deal with. Liang et al. [21, 22] used the nitrification/anammox/soil infiltration process to treat the landfill leachate in municipal solid waste landfill site. After 166 days of operation, the average removal rates of $\mathrm{NH}_{4}{ }^{+}-\mathrm{N}, \mathrm{TN}$ and $\mathrm{COD}$ reached $97 \%, 87 \%$ and $89 \%$ respectively, which fully proved the feasibility of the combined process, and anammox contributed to degradation of humic acid in landfill leachate. Liu et al. [23] used nitrification/anammox process to deal with the diluted landfill leachate anaerobic effluent. The operation was stable for 70 days, which is $\mathrm{NH}_{4}{ }^{+}-\mathrm{N}$ and $\mathrm{NO}_{2}{ }^{-}-\mathrm{N}$ removal rate remained above $93 \%$.

\section{Prospect}

Applications of anammox process, such as nitrification/anammox and CANON are continued to be developed and had more opportunities for application. However, there are still a lot of issues, which need to be solved and might come out new problems during the process in application. For example, the temperature influences the activity of bacteria anammox. Scale-up of anammox reactor should be carried out due to rapid start-up and influence mechanism. Effects of organic carbon source on anammox strains should be further investigated. The effects of nitrogen and carbon removal by anammox and denitrification should be studied. As for seed sludge, the use of cultivated sludge can reduce the start-up period. Also, by using the form of particles such as sludge or biofilm, sludge retention can be improved, which is very promising. At present, the biggest difficulty of municipal mainstream wastewater application is how to achieve partial nitrification and stable operation. DO control is essential in partial nitrification. Comparing with two stage anammox process, CANON is deemed as more conducive by using granular sludge or biofilm. If the above mentioned problem can be solved, the application of anammox process in treating municipal wastewater will surely have a bright future.

\section{Acknowledgements}

This research was supported by Guangxi Scientific Experiment Center of Mining, Metallurgy and Environment [grant number KH2012ZD004]; and a project for high-level innovation teams and outstanding scholars in Guangxi colleges and universities [grant number 002401013001].

\section{References}

[1] Joss A, Salzgeber D, Eugster J, et al. Full-scale nitrogen removal from digester liquid with partial nitritation and anammox in one SBR [J]. Environmental Science \& Technology, 2009, 43(14): 5301-5306.

[2] van der Star W R, Abma W R, Blommers D, et al. Startup of reactors for anoxic ammonium oxidation: Experiences from the first full-scale anammox reactor in Rotterdam [J]. Water Research, 2007, 41(18):4149-4163.

[3] FU Kunming, QIU Fuguo, ZUO Zaorong. Prospective Analysis of Application of Anaerobic Ammonia Oxidation Technology to Municipal Wastewater Treatment [J]. China Water \& Wastewater, 2015, 31(04): 8-13.

[4] Siegrist H, Salzgeber D, Eugster J, et al. Anammox brings WWTP closer to energy autarky due to increased biogas production and reduced aeration energy for N-removal [J]. Water Sci Technol, 2008, 57(3): 383-388.

[5] Chamchoi N, Nitisoravut S, Schmidt J E. Inactivation of anammox communities under concurrent operation of anaerobic ammonium oxidation (ANAMMOX) and denitrification [J]. Bioresour Technol, 2008, 99 (9): 3331 -3336. 
[6] Tan Fa, WANG Dunqiu, JIN Yue, et al. Effect of organic carbon source on nitrogen removal performance of one-stage anammox reactor [J]. Safety And Environmental Engineering, 2016, 23(04): 44-50.

[7] Strous M, van Gerven E, Kuenen J G, et al. Effects ofaerobic and microaerobic conditions on anaerobic ammonium-oxidizing (Anammox) sludge [J]. Appl Environ Microbiol, 1997, 63(6): 2446 2448.

[8] Hulle S W H V, Vandeweyer H J P, Meesschaert B D, et al. Engineering aspects and practical application of autotrophic nitrogen removal from nitrogen rich streams [J]. Chemical Engineering Journal, 2010, 162(1):1-20.

[9] Cema G, Wiszniowski J, Zabczynski S, et al. Biological nitrogen removal from landfill leachate by deammonification assisted by heterotrophic denitrification in a rotating biological contactor (RBC) [J]. Water Sci Technol, 2007, 55( 8/9): 35-42.

[10] Third KA, Sliekers AO, Kuenen JG, et al. The CANON system (completely autotrophic nitrogen-removal over nitrite) under ammonium limitation: Interaction and competition between three groups of bacteria [J]. Systematic and Applied Microbiology, 2001, 24(4): 588-96.

[11] Winkler M K, Kleerebezem R, van Loosdrecht M C M. Integration of anammox into the aerobic granular sludge process for main stream wastewater treatment at ambient temperatures [J]. Water Res, 2012, 46(1): 136-144.

[12] Van Dongen U, Jetten MS, Van Loosdrecht MCM. The SHARON-Anammox process for treatment of ammonium rich wastewater [J]. Water Science and Technology, 2001, 44(1): 153-60.

[13] Fux C, Boehler M, Huber P, et al. Biological treatment of ammonium-rich wastewater by partial nitritation and subsequent anaerobic ammonium oxidation (anammox) in a pilot plant [J]. Journal of Biotechnology, 2002, 99(3): 295-306.

[14] Kuypers M M, Sliekers A O, Lavik G, et al. Anaerobic ammonium oxidation by anammox bacteria in the Black Sea [J]. Nature, 2003, 422(6932):608.

[15] Fu Lixia, Wu Libo, Zhang Yiran, et al. Factors affecting the anammox process under low ammonia concentration [J]. Technology Of Water Treatment, 2010, 36(04): 50-55.

[16] HUANG Wei, QIN Guang-xu, ZHOU Jian, et al. Construction and Efficiency of Anaerobic Ammonium Oxidation System for Treatment of Low Strength Ammonia Wastewater [J]. China Water \& Wastewater, 2016, 32(17): 6-10.

[17] Hu Z, Lotti T, de Kreuk M, et al. Nitrogen removal by a nitritation-anammox bioreactor at low temperature [J]. Applied and Environmental Microbiology, 2013, 79(8): 2807-2812.

[18] van Dongen U, Jetten M S, van Loosdrecht M. The SHARON®-Anammox ${ }^{\circledR}$ process for treatment of ammonium rich wastewater [J].Water Science and Technology, 2001, 44(1): 153-160.

[19] Fux C, Boehler M, Huber P, et al. Biological treatment of ammonium-rich wastewater by partial nitritation and subsequent anaerobic ammonium oxidation (anammox) in a pilot plant [J]. Journal of Biotechnology, 2002, 99(3): 295-306.

[20] van der Star W R, Abma W R, Blommers D, et al. Startup of reactors for anoxic ammonium oxidation: Experiences from the first full-scale anammox reactor in Rotterdam [J]. Water Research, 2007, 41(18):4149-4163.

[21] Liang Z, Liu J. Landfill leachate treatment with a novel process: Anaerobic ammonium oxidation (Anammox) combined with soil infiltration system [J]. Journal of Hazardous Materials, 2008, 151(1): 202-212.

[22] Liang Z, Liu J, Li J. Decomposition and mineralization of aquatic humic substances (AHS) in treating landfill leachate using the Anammox process [J]. Chemosphere, 2009, 74(10): 1315-1320.

[23] Liu J, Zuo J, Yang Y, et al. An autotrophic nitrogen removal process: Short-cut nitrification combined with ANAMMOX for treating diluted effluent from an UASB reactor fed by landfill leachate [J]. Journal of Environmental Sciences, 2010, 22(5): 777-783. 